\title{
Acholeplasma florum, a New Species Isolated from Plants $\dagger$
}

\author{
R. E. MCCOY,${ }^{1 *}$ H. G. BASHAM, ${ }^{1}$ J. G. TULLY, ${ }^{2}$ D. L. ROSE, ${ }^{2}$ P. CARLE, ${ }^{3}$ AND J. M. BOVÉ ${ }^{3}$ \\ University of Florida Agricultural Research and Education Center, Fort Lauderdale, Florida $33314^{1}$; Laboratory of \\ Molecular Microbiology, National Institute of Allergy and Infectious Diseases, Frederick, Maryland 21701 ${ }^{2}$; and Institut \\ National de la Recherche Agronomique, Pont de la Maye 33140, France ${ }^{3}$
}

\begin{abstract}
Three acholeplasmas isolated from floral surfaces of healthy plants in Florida were found to be similar in their biochemical and serological properties. These organisms did not require serum or cholesterol for growth, although addition of some supplementary fatty acids (as represented by Tween 80 ) was necessary for growth to occur in serum-free medium. The three strains possessed biochemical properties typical of the Acholeplasmataceae and were distinguished from the nine previously recognized Acholeplasma species by serological and deoxyribonucleic acid-deoxyribonucleic acid hybridization techniques. The genome molecular weight of the three Acholeplasma strains was $10^{9}$, and the guanine-plus-cytosine content of the deoxyribonucleic acid was 27 to $28 \mathrm{~mol} \%$. On the basis of these results and other morphological, biological, and serological properties, we propose that these organisms represent a new species, Acholeplasma florum. Strain L1 (= ATCC 33453) is the type strain.
\end{abstract}

Plant surfaces, particularly flowers, have recently been proven to be fertile sites for isolation of members of the Mycoplasmatales (5, 11-13, 26). Members of the genus Acholeplasma have been recovered from flower surfaces in Florida and the central United States (26; McCoy, Basham, Tully, and Rose, Proc. 3rd Conf. Int. Org. Mycoplasmol., Custer, S.D., 1980, abstr. no. 88), from decaying coconut palm (Cocos nucifera L.) tissue in Jamaica (8), and from commercial vegetables intended for human consumption (19). Most of these isolations yielded strains of Acholeplasma laidlawii, Acholeplasma oculi, and Acholeplasma axanthum $(8,19)$, species that have been previously identified as having animal origins (22). However, although three isolates from citrus and ornamental flowers in Florida were related to each other, they were not related to any previously described Acholeplasma species. In this paper we define the basic characteristics of these flower surface acholeplasmas and describe their unique biological properties. We propose that these organisms be given taxonomic status as a new species of Acholeplasma.

\section{MATERIALS AND METHODS}

Acholeplasma strains. Details of the primary isolation technique for flower surface-inhabiting strains have been described previously (13). Strain PP2 was obtained from blossoms of Calliandra haematocephalus, whereas strains $\mathrm{L}^{\mathrm{T}}(\mathrm{T}=$ type strain) and GF1 were obtained from flowers of lemon (Citrus limon) and grapefruit (Citrus paradisi), respectively. Primary isolation was in MC (14) or SP-4 (24) broth medium without antibiotics. Each Acholeplasma strain was purified by a $3 \times$ filtration-cloning technique (21) before characterization studies were performed. The reference Acholeplasma species and other members of the Mycoplasmatales used in this study for comparative tests were stock cultures maintained in the Mycoplasma Section, Laboratory of Molecular Microbiology, National Institute of Allergy and Infectious Diseases, Frederick, Md. For other serological and biological comparisons we used stock cultures maintained at the University of Florida Agricultural Research and Education Center, Fort Lauderdale, Fla.

\footnotetext{
* Corresponding author.

$\dagger$ Florida Agricultural Experiment Station Journal Series No. 4782 .
}

Media and cultivation procedures. Isolates were routinely grown in MC broth or in the serum fraction medium described previously (17). We developed a serum-free medium that contained mycoplasma broth base (BBL Microbiology Systems, Cockeysville, Md.) supplemented with $10 \%$ fresh $25 \%$ yeast extract (Microbiological Associates, Bethesda, Md.), $0.5 \%$ glucose, $500 \mathrm{U}$ of penicillin $\mathrm{G}$ per $\mathrm{ml}, 0.002 \%$ phenol red, $0.5 \%$ bovine serum albumin, $0.04 \%$ Tween 80 , and $10 \mu \mathrm{g}$ of palmitic acid per $\mathrm{ml}$. Solid medium was prepared by adding $0.8 \%$ Noble agar (Difco Laboratories, Detroit, Mich.) or $1.0 \%$ agarose to the broth base before autoclaving. Cultures were grown aerobically at 25 to $30^{\circ} \mathrm{C}$.

Reversion studies. Primary isolation of strains $\mathrm{L1}^{\mathrm{T}}, \mathrm{PP2}$, and GF1 was in antibiotic-free media, and more than 30 passages were made in the absence of penicillin. In addition, transfer of these strains to penicillin G-containing serum fraction medium followed by serial passage in serum-free broth with transfer to blood agar plates at each passage was done to screen for bacterial revertants.

Filtration studies. Eighteen-hour cultures of strains $\mathrm{L1}^{\mathrm{T}}$, PP2, and GF1 were passed through cellulose acetate membrane filters having pore diameters of $0.65,0.45,0.3,0.22$, and $0.1 \mu \mathrm{m}$, and the numbers of color-changing units in the filtrates were determined from 10 -fold-serial dilutions in broth.

Morphology. Broth cultures of all three acholeplasmas were examined by phase-contrast microscopy and dark-field microscopy. Ammonium molybdate contrast preparations of whole organisms from cultures and ultrathin sections of pelleted organisms were examined by transmission electron microscopy as described previously (13).

Tests for biological and biochemical properties. Sterol requirements were determined by a broth culture method (16). A $2 \%$ inoculum was used, and the cells were harvested after $24 \mathrm{~h}$. Susceptibility to digitonin was assayed by a plate method, using MC agar medium and a paper disk (diameter, $6 \mathrm{~mm}$ ) soaked in $1.5 \%$ digitonin (10). The procedures used to determine carbohydrate fermentation and arginine and urea hydrolysis have been described previously (1). Production of $\beta$-D-glucosidase was tested by using the methods of Williams and Wittler (27) and Ern $\varnothing$ and Stipkovits (9). Carotenoid production was tested by the method of Tully and Razin (23).

Serological tests. Antisera to strains $\mathrm{L}^{\mathrm{T}}$, GF1, and PP2 were raised in rabbits as described previously (7). Hyperim- 
mune antisera were raised from strains maintained at the Mycoplasma Section, Laboratory of Molecular Microbiology, National Institute of Allergy and Infectious Diseases (MS), and the other antisera used represented the collection of antisera in the National Institutes of Health Mycoplasma Reference Reagent Program (4) (NIH). We used antisera to Acholeplasma axanthum H86NT (MS), Acholeplasma equifetale N93 (MS), Acholeplasma granularum BTS $39^{\mathrm{T}}$ (NIH), Acholeplasma hippikon $\mathrm{Cl}^{\mathrm{T}}$ (MS), Acholeplasma laidlawii $\mathrm{PG8}^{\mathrm{T}}$ (NIH), Acholeplasma modicum PG49 ${ }^{\mathrm{T}}$ (MS), Acholeplasma morum 72-043 ${ }^{\mathrm{T}}$ (MS), Acholeplasma oculi $19 \mathrm{~L}^{\mathrm{T}}$ (MS), Acholeplasma parvum $\mathrm{H}_{23 \mathrm{M}^{\mathrm{T}}}$ (MS), Mycoplasma alvi Ilsley ${ }^{\mathrm{T}}$ (MS), Mycoplasma anatis $1340^{\mathrm{T}}$ (NIH), Mycoplasma bovigenitalium $\mathrm{PG}^{\mathrm{T}}(\mathrm{NIH})$, Mycoplasma bovirhinis $\mathrm{PG}_{43^{\mathrm{T}}}$ (NIH), Mycoplasma bovoculi $\mathrm{M} 165 / 69^{\mathrm{T}}$ (MS), Mycoplasma californicum $\mathrm{ST}^{\mathrm{T}}$ (MS), Mycoplasma canis $\mathrm{PG}_{14}{ }^{\mathrm{T}}$ (NIH), Mycoplasma capricolum California $\mathrm{Kid}^{\mathrm{T}}$ (MS), Mycoplasma caviae $\mathrm{G} 122^{\mathrm{T}}$ (MS), Mycoplasma citelli RG2C $^{\mathrm{T}}$ (MS), Mycoplasma columborale MMP4 ${ }^{\mathrm{T}}$ (MS), $M y$ coplasma conjunctivae HRC581 ${ }^{\mathrm{T}}$ (MS), Mycoplasma cynos H831 $1^{\mathrm{T}}$ (MS), Mycoplasma dispar $462 / 2^{\mathrm{T}}$ (MS), Mycoplasma edwardii PG24 ${ }^{\mathrm{T}}$ (MS), Mycoplasma equigenitalium $\mathrm{T} 37^{\mathrm{T}}$ (MS), Mycoplasma fastidiosum $\mathrm{H}_{822^{\mathrm{T}}}$ (MS), Mycoplasma feliminutum Ben ${ }^{\mathrm{T}}$ (MS), Mycoplasma felis Cat27 (MS), Mycoplasma fermentans $\mathrm{PG}^{\mathrm{T}} \mathrm{T}^{\mathrm{T}}$ (NIH), Mycoplasma flocculare $\mathrm{Ms}^{\mathrm{T}} \mathrm{2}^{\mathrm{M}}$ (M), Mycoplasma gallinaceium SA-J (MS), Mycoplasma gallisepticum $\mathrm{PG}^{\mathrm{T}}{ }^{\mathrm{T}}$ (NIH), Mycoplasma gallopavonis WR1 $1^{\mathrm{T}}$ (MS), Mycoplasma genitalium $\mathrm{G} 37^{\mathrm{T}}$ (MS), Mycoplasma hyopneumoniae $\mathrm{J}^{\mathrm{T}}$ (MS), Mycoplasma hyorhinis BTS7 ${ }^{\mathrm{T}}$ (NIH), Mycoplasma iowae $695^{\mathrm{T}}$ (MS), Mycoplasma moatsii MK405 ${ }^{\mathrm{T}}$ (MS), Mycoplasma molare $\mathrm{H} 542^{\mathrm{T}}$ (MS), Mycoplasma mycoides subsp. capri $\mathrm{PG}^{\mathrm{T}}$ (MS), Mycoplasma mycoides subsp. mycoides B3 (MS), Mycoplasma neurolyticum Type $\mathrm{A}^{\mathrm{T}}$ (NIH), Mycoplasma ovipneumoniae $\mathrm{Y}^{\mathrm{T}}{ }^{\mathrm{T}}$ (MS), Mycoplasma pneumoniae $\mathrm{FH}^{\mathrm{T}}$ (NIH), Mycoplasma pullorum $\mathrm{CKK}^{\mathrm{T}}$ (MS), Mycoplasma pulmonis $\mathrm{PG} 34^{\mathrm{T}}$ (NIH), Mycoplasma putrefaciens $\mathrm{KS}^{\mathrm{T}}{ }^{\mathrm{T}}$ (MS), Mycoplasma sualvi Mayfield $\mathrm{B}^{\mathrm{T}}$ (MS), Mycoplasma verecundum $107^{\mathrm{T}}$ (MS), Mycoplasma sp. strain B5P (MS), Mycoplasma sp. strain California calf (MS), Mycoplasma sp. strain 70-159 (MS), Mycoplasma sp. strain M1 (MS), Mycoplasma sp. strain 831-C4 (MS), and Mycoplasma sp. strain Gough (MS). Disk growth inhibition tests (3) were performed on serum fraction or MC agar medium, and direct plate immunofluorescence antibody tests were performed by using fluorescein-conjugated antisera to the organisms listed above (6). A direct enzyme-linked immunosorbent assay was performed as previously described (7).

Polyacrylamide gel electrophoresis. One-dimensional slab polyacrylamide gel electrophoresis was performed as described by Mouches and Bové (14). Whole cell proteins were solubilized in $16 \%$ glycerol- $3 \%$ sodium dodecyl sulfate$0.17 \%$ dithiothreitol, diluted in gel buffer, and electrophoresed on $10 \%$ acrylamide gels at $100 \mathrm{~V}$ (constant voltage; ca. $160 \mathrm{~mA}$ ). The gels were stained with Coomassie brilliant blue or silver stains (BioRad Laboratories, Richmond, Calif.).

DNA characteristics. The guanine-plus-cytosine contents of the deoxyribonucleic acids (DNAs) of the three Acholeplasma strains were determined from the buoyant density profiles established by equilibrium density gradient centrifugation in $\mathrm{CsCl}_{2}$ in Spinco model $\mathrm{E}$ and MSE Centriscan 10 analytical ultracentrifuges, using the method of Schildkraut et al. (18). The DNAs of Spiroplasma citri and Escherichia coli were used as reference standards. Genome sizes were determined from kinetic complexity by the method of Wetmur and Davidson (25).

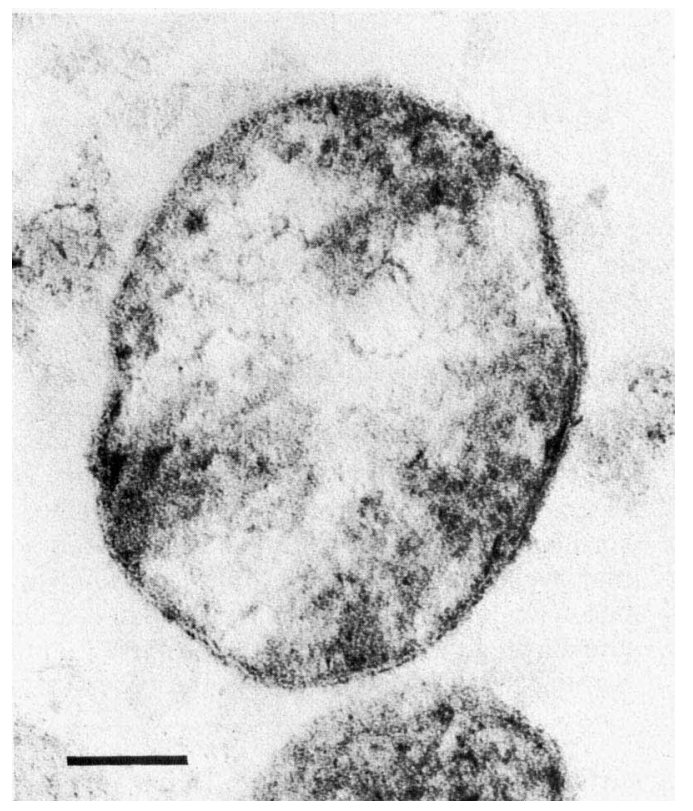

FIG. 1. Electron micrograph of an ultrathin section of A. florum strain $\mathrm{L1}^{\mathrm{T}}$. Bar $=0.1 \mu \mathrm{m}$.

\section{RESULTS}

Morphological and cultural properties. Broth cultures of strains $\mathrm{PP} 2, \mathrm{L1}^{\mathrm{T}}$, and $\mathrm{GF1}$ grew rapidly, producing heavy turbidity in $18 \mathrm{~h}$ in $\mathrm{MC}$ broth, serum fraction broth, or serum-free Tween 80 broth. Light microscopy revealed round forms and heavy clumping of cells to form the suspended microcolonies responsible for the turbidity. Electron microscopy of ammonium molybdate-contrasted cells also revealed some clumping (13), and ultrathin sections showed a trilaminar unit membrane and no evidence of cell wall material outside the cytoplasmic membrane (Fig. 1). The organisms grew at 18 to $37^{\circ} \mathrm{C}$, but not at $40^{\circ} \mathrm{C}$. No growth occurred in serum-free media without the fatty acids provided by the Tween 80 -palmitic acid-bovine serum albumin supplement. The colonies on agar media exhibited typical fried egg morphology and ranged in size from 200 to $300 \mu \mathrm{m}$ in diameter (Fig. 2).

Reversion studies. No reversion to bacterial forms was observed after 30 passages in antibiotic-free media, nor were bacterial forms observed after transfer to penicillin- $G$ containing media and subsequent passage in serum-free medium.

Filtration studies. Cloned broth cultures of all three Acholeplasma strains contained $10^{7}$ to $10^{8}$ color-changing units per $\mathrm{ml}$ of medium (Table 1). The number of color-changing units decreased logarithmically with decreasing pore size after filtration through filters having pore sizes of $0.65,0.45$, $0.3,0.22$, and $0.1 \mu \mathrm{m}$. No organisms were detected in the filtrate that passed through $0.1 \mu \mathrm{m}$ pores.

Biochemical and biological properties. All three strains fermented glucose but not mannose, did not hydrolyze esculin or arbutin, did not produce carotenoid pigments, did not hydrolyze arginine or urea, and did not liquefy coagulated serum or hemadsorb guinea pig erythrocytes. Although all three strains developed 2- to 4-mm radial inhibition zones to digitonin on $20 \%$ horse serum agar, no response to added cholesterol was detected when the broth culture method was used (Table 2). 


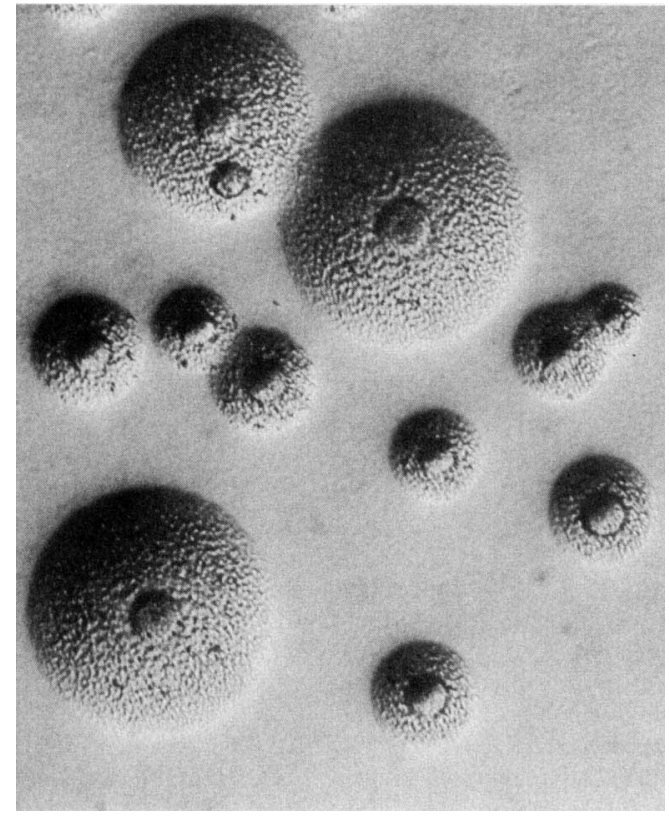

FIG. 2. Colonies of A. floridum strain $\mathrm{L1}^{\mathrm{T}}$ on $20 \%$ horse serum agar $\left(48 \mathrm{~h}, 37^{\circ} \mathrm{C}\right)$.

Serological tests. Growth inhibition and plate immunofluorescence tests indicated that the three Acholeplasma strains which we studied are distinct from all other Acholeplasma species and the glucose-fermenting Mycoplasma species. Reciprocal growth inhibition tests and enzyme-linked immunosorbent assays performed on the three strains confirmed that they were related to each other but not to $A$. laidlawii (Table 3).

Polyacrylamide gel patterns. The one-dimensional polyacrylamide gel electrophoresis patterns of the three flower Acholeplasma strains were similar and were readily distinguished from those of $A$. laidlawii (Fig. 3). The silver stain produced more and sharper bands than the usual Coomassie brilliant blue gel stain.

DNA characteristics. The guanine-plus-cytosine contents of the DNAs of the three acholeplasma strains averaged 27.3 $\pm 1 \mathrm{~mol} \%$, as determined independently in two laboratories (Institut National de la Recherche Agronomique, Bordeaux, France, and John Innes Institute, Norwich, England). The genome molecular weight was $1.05 \times 10^{9} \pm 0.3 \times 10^{9}$.

\section{DISCUSSION}

A unique feature of the three strains described here is the fact that they were isolated from the surfaces of subtropical flowers. This is the first documented evidence of the isola-

TABLE 1. Passage of A. florum strains $\mathrm{L1}^{\mathrm{T}}, \mathrm{GF1}$, and PP2 through cellulose acetate filters of varying pore sizes

\begin{tabular}{lccc}
\hline $\begin{array}{c}\text { Filter pore size } \\
(\mu \mathrm{m})\end{array}$ & \multicolumn{3}{c}{ No. of color-changing units/ml } \\
\cline { 2 - 4 } & $\mathrm{L} 1^{\mathrm{T}}$ & $\mathrm{GF} 1$ & $\mathrm{PP2}$ \\
\hline Unfiltered & $10^{8}$ & $10^{7}$ & $10^{7}$ \\
0.65 & $10^{6}$ & $10^{8}$ & $10^{7}$ \\
0.45 & $10^{6}$ & $10^{6}$ & $10^{7}$ \\
0.30 & $10^{4}$ & $10^{3}$ & $10^{6}$ \\
0.22 & $<10$ & $<10$ & $10^{2}$ \\
0.10 & $<10$ & $<10$ & $<10$ \\
\hline
\end{tabular}

TABLE 2, Effect of cholesterol on the growth of strain $\mathrm{L1}^{\mathrm{T}}$ in serum-free medium

\begin{tabular}{cc}
\hline Cholesterol concn $(\mu \mathrm{g} / \mathrm{ml})$ & Amt of cell protein $(\mathrm{mg})^{a}$ \\
\hline $0^{b}$ & $<0.02$ \\
$0^{c}$ & $<0.02$ \\
$0^{d}$ & 2.45 \\
$1.0^{e}$ & 2.55 \\
5.0 & 2.25 \\
10.0 & 2.75 \\
20.0 & 2.55 \\
Control $^{f}$ & 4.30 \\
\hline
\end{tabular}

${ }^{a}$ Amount of protein in the cell pellet obtained from $100 \mathrm{ml}$ of medium.

${ }^{b}$ Serum-free base medium alone.

$c$ Serum-free base medium supplemented with $0.5 \%$ albumin and $10 \mu \mathrm{g}$ of palmitic acid per $\mathrm{ml}$.

${ }^{d}$ Serum-free base medium supplemented with $0.5 \%$ albumin, 10 $\mu \mathrm{g}$ of palmitic acid per $\mathrm{ml}$, and $0.04 \%$ Tween 80 .

${ }^{e}$ Serum-free base medium supplemented with $0.5 \%$ albumin, 10 $\mu \mathrm{g}$ of palmitic acid per $\mathrm{ml}, 0.04 \%$ Tween 80 , and cholesterol.

${ }^{f}$ Serum-free base medium supplemented with $1 \%$ bovine serum fraction.

tion of new, non-sterol-requiring mycoplasmas from sources other than animals. Subsequent isolations of related organisms have been made from flowers in temperate regions (Colorado, Nebraska, and Illinois) (26). The relationship of the temperate region isolates to the Florida strains was demonstrated by nucleic acid hybridization and fluorescent antibody serological tests. It is yet to be determined whether flower surfaces represent primary habitats for these organisms or whether the plant surfaces are just resting sites. We suspect that insects carry the flower mycoplasmas from site to site, and indeed several flower spiroplasmas have been demonstrated to be pathogenic to insects $(2,7,15)$.

The morphology, the filterability, the guanine-plus-cytosine content of the DNA, and the absence of reversion to bacteria of these organisms indicate that they belong to the

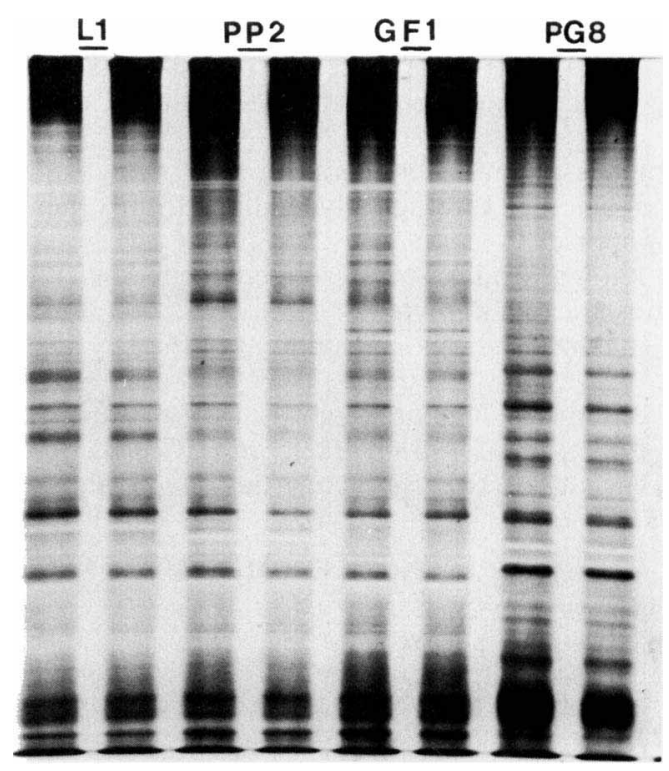

FIG. 3. Polyacrylamide gel electrophoresis patterns of whole cell proteins of $A$. florum strains $\mathrm{L1}^{\mathrm{T}}$, PP2, GF1 and A. laidlawii PG8. 
TABLE 3. Comparison of A. florum $\mathrm{L1}^{\mathrm{T}}, \mathrm{GF} 1$, and PP2 and A. laidlawii PG8 by the growth inhibition test and the enzyme-linked immunosorbent assay

\begin{tabular}{|c|c|c|c|c|c|c|c|c|}
\hline \multirow{3}{*}{$\begin{array}{l}\text { Anti- } \\
\text { gen }\end{array}$} & \multicolumn{8}{|c|}{ Antiserum } \\
\hline & \multicolumn{2}{|c|}{ PG8 } & \multicolumn{2}{|c|}{$\mathrm{L}^{\mathrm{T}}$} & \multicolumn{2}{|c|}{ GF1 } & \multicolumn{2}{|c|}{ PP2 } \\
\hline & $\begin{array}{l}\text { Zone of growth } \\
\text { inhibition }(\mathrm{mm})\end{array}$ & $\begin{array}{l}\text { \% Of homolo- } \\
\text { gous reaction }^{a}\end{array}$ & $\begin{array}{l}\text { Zone of growth } \\
\text { inhibition }(\mathrm{mm})\end{array}$ & $\begin{array}{l}\text { \% Of homolo- } \\
\text { gous reaction }\end{array}$ & $\begin{array}{l}\text { Zone of growth } \\
\text { inhibition }(\mathrm{mm})\end{array}$ & $\begin{array}{l}\text { \% Of homolo- } \\
\text { gous reaction }\end{array}$ & $\begin{array}{l}\text { Zone of growth } \\
\text { inhibition (mm) }\end{array}$ & $\begin{array}{l}\% \text { Of homolo- } \\
\text { gous reaction }\end{array}$ \\
\hline PG8 & 3 & 100 & 0 & 3 & 0 & 7 & 0 & 9 \\
\hline $\mathrm{L}^{\mathrm{T}}$ & 0 & 0 & 1.5 & 100 & 1.5 & 45 & 3.5 & 29 \\
\hline GF1 & 0 & 0 & 2 & 15 & 2 & 100 & 4 & 35 \\
\hline PP2 & 0 & 0 & 1 & 25 & 1 & 42 & 5 & 100 \\
\hline
\end{tabular}

${ }^{a}$ Percentage of homologous reaction in the enzyme-linked immunosorbent assay.

class Mollicutes. Their lack of a sterol requirement for growth, their ability to grow aerobically, and their genome molecular weight place them in the family Acholeplasmataceae and the genus Acholeplasma. The results of extensive serological tests indicate the lack of relationship of these strains to any of the nine previously established Acholeplasma species or to all known fermenting Mycoplasma species. Additional evidence that these isolates represent a new Acholeplasma species comes from the DNA-DNA hybridization data published previously (20). We propose that these organisms be named Acholeplasma florum (flo'rum. sp. nov. L.gen. pl.n. florum, of flowers, indicating the recovery site of the organism). The specific epithet refers to the site of isolation of the strains. Strain L1 is designated the type strain; a cloned line of this strain has been deposited in the American Type Culture Collection as strain ATCC 33453.

Acholeplasma florum sp. nov. Ultrathin sections reveal ovoid particles with a single trilaminar membrane and no cell wall.

Cells pass through filters having $0.45-\mu \mathrm{m}$ pores, but most are retained on filters having $0.22-\mu \mathrm{m}$ pores.

Colonies on agar are umbonate.

Cultures are resistant to penicillin, and no reversion to walled forms occurs in the absence of penicillin.

No growth response occurs when supplementary cholesterol is added, although digitonin is slightly inhibitory to growth on horse serum-containing agar.

Films and spots are produced on serum-containing media.

Glucose is utilized, but mannose, arginine, and urea are not.

Carotenes are not produced, nor is $\beta$ - $D$-glucosidase.

The species is serologically distinct from other Acholeplasma species.

The known strains were isolated from flower surfaces; other hosts are unknown.

The guanine-plus-cytosine content of the DNA is $27.3 \pm 1$ mol\%.

The genome molecular weight is $1.05 \times 10^{9} \pm 0.3 \times 10^{9}$.

The type strain is strain L1 (= ATCC 33453). The type strain has all of the characteristics given above for the species.

\section{ACKNOWLEDGMENTS}

We acknowledge technical assistance and electron microscopy by D. S. Williams and the assistance and advice of M. J. Daniels and P. G. Markham. Portions of this study were completed during a faculty development leave by R. E. M. at the John Innes Institute, Norwich, England.

\section{LITERATURE CITED}

1. Aluotto, B. B., R. G. Wittler, C. O. Williams, and J. E. Faber. 1970. Standardized bacteriologic techniques for the character- ization of Mycoplasma species. Int. J. Syst. Bacteriol. 20:3558.

2. Clark, T. B. 1977. Spiroplasma sp., a new pathogen in honey bees. J. Invertr. Pathol. 29:112-113.

3. Clyde, W. A., Jr. 1964. Mycoplasma species identification based upon growth inhibition by specific antisera. J. Immunol. 92:958-963.

4. Cunningham, S. (ed.). 1978. NIAID catalog of research reagents. Department of Health, Education and Welfare publication (NIH) 78-899. National Institutes of Health, Bethesda, Md.

5. Davis, R. E. 1978. Spiroplasmas associated with flowers of the tulip tree. Can. J. Microbiol. 24:954-959.

6. Del Giudice, R. A., N. F. Robillard, and T. R. Carski. 1967. Immunofluorescence identification of Mycoplasma on agar by use of incident illumination. J. Bacteriol. 93:1205-1209.

7. Dowell, R. F., H. G. Basham, and R. E. McCoy. 1981. Influence of five spiroplasma strains on growth rate and survival of Galleria mellonella larvae. J. Invertr. Pathol. 37:231-235.

8. Eden-Green, S. J., and J. G. Tully. 1979. Isolation of Acholeplasma spp. from coconut palms affected by lethal yellowing disease in Jamaica. Curr. Microbiol. 2:311-316.

9. Ernø, H., and L. Stipkovits. 1973. Bovine mycoplasmas: cultural and biochemical studies. II. Acta Vet. Scand. 14:450-463.

10. Freundt, E. A., B. E. Andrews, H. Ernø, M. Kunze, and F. T. Black. 1973. The sensitivity of Mycoplasmatales to sodium polyanethol-sulfonate and digitonin. Zentralbl. Bakteriol. Parasitenkd. Infektionskr. Hyg. Abt. 1 Orig. 225:104-112.

11. Junca, P., C. Saillard, J. Tully, O. Garcia-Jurado, J.-R. Degorce-Dumas, C. Mouches, J.-C. Vignault, R. Vogel, R. McCoy, R. Whitcomb, D. Williamson, J. Latrille, and J. M. Bové. 1980. Charactérisation de spiroplasmes isolés d'insectes et de fleurs de France continentale, de Corse et du Maroc. Proposition pour une classification des spiroplasmes. C. R. Acad. Sci. 290:12091212 .

12. McCoy, R. E., H. G. Basham, and R. E. Davis. 1982. Powder puff spiroplasma, a new epiphytic mycoplasma. Microbial Ecol. 8:169-180.

13. McCoy, R. E., D. S. Williams, and D. L. Thomas. 1979. Isolation of mycoplasmas from flowers, p. 75-81. In H. J. Su and R. E. McCoy (ed.), Proceedings of the Republic of ChinaUnited States Cooperative Science Seminar on Mycoplasma Diseases of Plants. National Science Council Symposium Series, no. 1. National Science Council, Taipei, Taiwan.

14. Mouches, C., and J. M. Bové. 1983. Electrophoretic characterization of mycoplasma proteins, p. 241-255. In S, Razin and J. G. Tully (ed.), Methods in mycoplasmology, vol. 1. Academic Press, Inc., New York.

15. Mouches, C., J. M. Bové, J. G. Tully, D. L. Rose, R. E. McCoy, P. Carle-Junca, M. Garnier, and C. Saillard. 1983. Spiroplasma apis, a new species from the honey bee. Ann. Microbiol. (Paris) 134A:383-397.

16. Razin, S., and J. G. Tully. 1970. Cholesterol requirement of mycoplasmas. J. Bacteriol. 102:306-310.

17. Rose, D. L., J. G. Tully, and R. A. Del Giudice. 1980. Acholeplasma morum, a new non-sterol-requiring species. Int. J. Sys. Bacteriol. 30:647-654. 
18. Schildkraut, C. L., J. Marmur, and P. Doty. 1962. Determination of the base composition of deoxyribonucleic acid from its buoyant density in CsCl. J. Mol. Biol. 4:430-433.

19. Somerson, N. L., J. P. Kocka, D. Rose, and R. A. Del Giudice. 1982. Isolation of acholeplasmas and a mycoplasma from vegetables. Appl. Environ. Microbiol. 43:412-417.

20. Stephens, E. B., G. S. Aulakh, R. E. McCoy, D. L. Rose, J. G. Tully, and M. F. Barile. 1981. Lack of genetic relatedness among animal and plant acholeplasmas by nucleic acid hybridization. Curr. Microbiol. 5:367-370.

21. Subcommittee on the Taxonomy of Mollicutes. 1979. Proposal of minimal standards for descriptions of new species of the class Mollicutes. Int. J. Syst. Bacteriol. 29:172-180.

22. Tully, J. G. 1979. Special feature of the acholeplasmas, p. 431449. In M. F. Barile and S. Razin (ed.), The mycoplasmas, vol. 1. Cell biology. Academic Press, Inc., New York.
23. Tully, J. G., and S. Razin. 1968. Physiological and serological comparisons among strains of Mycoplasma granularum and Mycoplasma laidlawii. J. Bacteriol. 95:1504-1512.

24. Tully, J. G., R. F. Whitcomb, H. F. Clark, and D. L. Williamson. 1977. Pathogenic mycoplasmas; cultivation and vertebrate pathogenicity of a new spiroplasma. Science 195:892-894.

25. Wetmur, J. G., and M. Davidson. 1968. Kinetics of renaturation of DNA. J. Mol. Biol. 31:349-370.

26. Whitcomb, R. F., J. G. Tully, D. L. Rose, E. B. Stephens, A. Smith, R. E. McCoy, and M. F. Barile. 1982. Wall-less prokaryotes from fall flowers in central United States and Maryland. Curr. Microbiol. 7:285-290.

27. Williams, C. O., and R. G. Wittler. 1971. Hydrolysis of aesculin and phosphatase production by members of the order $M y c o-$ plasmatales which do not require sterol. Int. J. Syst. Bacteriol. 21:73-77. 